$\frac{\mathrm{DE}}{\mathrm{G}} \stackrel{\substack{\text { DE GRUYTER } \\ \text { OPEN }}}{\text { DOI 10.1515/ethemes-2014-0025 }}$

\title{
THE INFLUENCE OF PERCEIVED VALUE DIMENSIONS ON CUSTOMER LOYALTY
}

\author{
Srđan Šapić \\ University of Kragujevac, Faculty of Econmics, Serbia \\ \sapic@kg.ac.rs \\ Snežana Topalović \\ University of Kragujevac, Faculty of Econmics, Serbia \\ $\triangle$ topalovicsneza@gmail.com \\ Veljko Marinković \\ University of Kragujevac, Faculty of Econmics, Serbia \\ $\bowtie$ vmarinkovic@kg.ac.rs
}

\section{UDC}

658.6:338.486.22

658.8.012.12

Original

scientific paper

Received:

21.10.2014

Accepted:

29.12.2014

\begin{abstract}
In conditions of intense competition, it is not enough to achieve only customer satisfaction. The marketing-oriented companies must be focused on building long-term customer loyalty. Creation and delivery of superior values are the key activities to achieve and maintain competitive advantage. This study seeks to examine how the different value dimensions of travel agencies' services affect both dimensions of loyalty: the intention of using the same services again and recommending them to others. Primary data were collected through questionnaire method. In the study, descriptive statistics, correlation and multi-point regression were used for data analysis. The results of survey point out two key dimensions of perceived value that achieve a statistically significant effect on loyalty: quality of interaction and value for money. Identification of key dimensions of perceived value as an initiator of loyalty is essential for service-oriented companies, because in this way they increase opportunities for improving business relationships with clients, in the future.
\end{abstract}

Key words: perceived value, dimensions of values, word of mouth, repurchase intention, service companie 


\section{Introduction}

Customer orientation is an integral part of business policy of marketingoriented companies. In order to achieve long-term profitability and to establish long-term relationships with customers, the companies must base their business on studying and identifying the needs and desires of customers, creating offers with competitive advantage and coordinating the internal activities. Customers' needs and attitudes are in the focus of marketing activities. First of all, businesses must explore the attitudes of customers, in order to formulate and implement marketing strategies on the basis of the results obtained. The marketing concept is based on the assumption that the strategy of the company must be in accordance with customers' requirements since it will lead to delivering superior value and to customer satisfaction. However, satisfaction is not enough for making profit in the long term, bearing in mind that in some situations it provides only a short-run profit. In order to provide the corresponding level of long-term profitability, it is necessary to make loyal customers out of the satisfied ones. Successful implementation of the marketing concept means that the company is oriented towards satisfying the demands of target customers, thereby making sure that the offer is better than those of the competition. To achieve this, it is necessary to coordinate marketing activities with other activities in the company (purchase, production, finance etc.)

With the objective of identifying and examining the influence that key dimensions of value of travel agencies' services have on customer loyalty, an empirical research has been conducted on a sample of 157 respondents. Primary data were collected through the questionnaire method in the territory of the Raska District, while descriptive statistics, correlation and multi-point regression were used for data analysis. The use of two multi-point regressions resulted in identifying significant loyalty drivers. The importance of the conducted research refers to the selection of the value dimensions that reflect the future business relationship between travel agencies and clients. These are dimensions that refer to the prestige of travel agencies, the economic value of services and the quality of interaction between employees and clients. Although there is an increasing number of studies performed by foreign authors who are focused on examining the perceived value of services and discovering the importance of value for loyalty, in the Western Balkans this area is becoming a subject of interest and research only in the last years, so the studies in this field are present in a lesser extent.

\section{Literature Review}

\subsection{The Concept of Perceived Value}

The concept of value for customers is very complex and cannot be defined precisely, bearing in mind that consumers of products or services expect various 
benefits. In addition, the definition of value depends also on the context in which it is applied, since it has a wide use in many fields, including also the service sector. The value is usually observed from the perspective of the customer. In marketing literature the most commonly used definition speaks about the value as a difference between benefits and sacrifices derived from buying and using the products and services (Holbrook, 2007). Accordingly, the value includes a set of different benefits that customers get when investing their money, time and energy in purchasing and using the products and/or services. Woodruff (1997) describes it as a customer's preference for and evaluation of those product attributes, attributes of performances and experiences arising from use of products that meet his needs. The value can be seen as a difference between all benefits and all costs of a particular product in comparison to the competing products. Customers cannot clearly and precisely perceive all the benefits offered by products/services, or the financial investment needed for their purchase and consumption, so in the perception of the value they rely on evaluation of products/services. Therefore, the perceived value can be viewed as a relationship between perceived benefits and perceived cost of products and services. The perceived customer value includes perceived attributes of products and services and perceived attributes of substitutes, while the perceived price comprises the perceived price of products and services and the perceived price of substitutes (Johnson and Weinstein, 2004).

As noted, customers do not buy a product/service, but various benefits that derive from them. Customers can enjoy direct or indirect benefits by using products and services. Direct benefits arise from products and services, while indirect benefits are achieved through business relationship (Lapierre, 2000). Direct benefits are categorized as a functional part of the value, while the indirect ones are viewed as an aspect of social and psychological value (Sweeny and Webb, 2007). Petrick (2002) claims that these benefits include tangible and intangible elements, the willingness of employees to meet the demands of customers, social rewards and experience. Beside physical attributes of the product, customers expect also various benefits during the purchase process itself, from the kindness and receptiveness of the staff, from the provision of additional services (servicing, installation etc.), but they also want to feel satisfied and comfortable during and after the purchase of the products/services. Which benefit elements in value creation will be crucial depends primarily on the type of the product/service and on ultimate aims of the customers. While some products include functionality and durability as the most significant benefits, in case of some services, such as, for instance, tourist services, the greatest significance in the total value represents a pleasant feeling, enjoyment and satisfaction that appear after consumption of services, as a result of experience gained during the travel. 
Costs as the second element of the value include financial expenses, time spent, physical and psychological effort that customers invest in the process of procurement and purchase of the product (Milisavljević, Maričić, Gligorijević, 2007, pp. 39-40). Based on the findings of some studies, it is stated that financial expense is the only element of costs (Teas and Agarwal, 2000; Murphy, 2002). However, beside financial expenditures, also other investments are necessary in order to procure, owe and use a product/service. Just like benefits derived from products/services, required investments may also be different. In marketing literature the common name for all expenditures is referred as a sacrifice. There are sacrifices that are related to physical effort, such as energy, exertion and time invested by the customer in the purchasing process. With the increase in physical effort, the value of product or service decreases. When making decision on purchase, customers dispose of numerous information on and characteristics of the value of competing products or services, thus they invest also a mental effort. Every customer tends to minimize the risk when making decision on purchase with an aim to reduce mental effort, which also reduces the sacrifice. Regardless of which definition is used, there are two elements of value they have in common: benefits and sacrifices. When assessing alternatives in the phase of purchase, customers decide for the one whose perceived benefits (quality, politeness, speed of delivery, reputation etc.) exceed the perceived expenditures (money, time, effort) (Stanković and Đukić, 2009 , p. 74). Namely, we talk about customer value when the benefits from a particular product or service exceed the investments required for their purchase and consumption.

Because of its complexity, the customer value is characterized by the following features (Maričić and Đorđević, 2012):

- relativity,

- subjectivity,

- comparability,

- value as a situational category.

Customer value is a relative size which cannot be measured by numerical indicators. Subjectivity is one of the key characteristics of the value, which implies that the value is based on a subjective assessment of individual customers. Namely, the customer value is usually not seen as an objective dimension determined by the company, but it is something estimated by the customers (Hu et al., 2009). Customer estimates the value of a particular product/service on the basis of personal experience of using them, and/or by collecting information on their performances from the environment. The complexity of the customer value results from the fact that it is a comparative category. The comparative value of specific product/service is determined by comparison of the benefits offered by other products/services on the market, 
which meets the same need. In purchase decision-making, customers evaluate a large number of potential products, based on the benefits they offer and the costs required to obtain them. How will customers assess the value of a specific product/service depends also on various current situations and places in which it is assessed. The value of the same product may be estimated in different way, depending on external factors which influence the elements of the value. One of the value characteristics is also its variability. Customers estimate the value in different ways, as their expectations and preferences are heterogeneous. This means that the value of the same product will not have the same importance and significance for each customer. Instrumentality means that the products and services are created in accordance with customers' needs and desires. Values are observed in the hierarchy, where at the lowest level are those values which meet the basic needs of customers. Diversity of value is one more in a series of its characteristics. The higher the level in the hierarchical structure, the greater will be the diversity of the value observed by the customer. The fulfillment with one value will cause among customers also the utility of another value, which indicates the synergistic effect of values. Values are also characterized by specificity since they differ from one another in the role that the customer has in purchasing process (Milisavljević, Maričić, Gligorijević 2007, pp. 39-40).

\subsection{Perceived Value Dimensions}

How will the value of a particular product or service be assessed depends on the customer's personal assessment. Some customers may find a specific product insignificant, while for the others, it might be very important. Sweeny and Soutar (2001) have set the customer perceived value scale which explains value dimensions of products. Because of the need to measure the value of services perceived by the customers, Petrick (2002) has developed a model for measuring the key elements of percieved value of services in the hotel industry. The model contains 18 statements grouped into five main entities, each of which reffers to one of the following factors: quality, reputation, emotional value, monetary and non-monetary cost. Nasution and Mavondo (2008) have arranged the following three perceived value dimensions according to the level of significance:

- reputation,

- value for money,

- prestige.

It is crucial to determine how important is the reputation of a service company to customers and to what extent it influences their purchasing decision. The reputation of a specific service organization refers first of all to quality level in providing services. The higher the quality level, the better will be service organization's reputation. Thus, reputation can be seen as a part of quality, but 
also of emotional value (Nasution and Mavondo, 2008). When it comes to travel agencies, every client wants to have a pleasant experience not only during the consumption, but also after purchasing a tourist product/service. The manner in which personnel treats its clients has a great impact on building the agency's reputation. Reputation as a value element determines emotional reactions of customers, which may be positive or negative as well as weak or strong. Serviceoriented companies with good reputation provide their clients with superior value achieving thereby efficient communication (Ou and Abratt, 2006).

Another important dimension in assessment of the value of services or products represents the value for money. It is most often identified with economic value. Customers determine it also by comparing the benefits they receive through purchasing a service and costs required for obtaining the same. Modern customers are even more careful during purchasing process and want to get an appropriate value for the money they invest. They want to have a highquality service and they are willing to pay for it. Gallarza and Saura (2006) have shown in their study that there is a relationship between quality, value, satisfaction and loyalty in customer behavior.

One of the key dimensions of customer value is also prestige. Customers primarily require a high-quality product and/or service for which they are willing to pay, but they also want a status and prestige that the use of such product and/or service brings. Prestige as a part of social value means customers' perception influenced by the people from their environment whose opinion is valued and respected and who see a particular company and its products and/or services as a status symbol (Bergami and Bagozzi, 2000). The main value of prestige arises from the tendency to demonstrate the social status to other community members. Hence customers purchase and use branded products and services which symbolize power and financial status of the owner. Bergami and Bagozzi (2000) argue that the company's prestige leads to identifying customers with them, respectively the use of prestigious products and/or services creates a feeling of a fulfilled personality.

Aside from the dimensions mentioned, of great importance for the perceived value of products and services is also a quality of interaction ("relationship benefits") (Olaru et al., 2008). In the interaction between providers and customers of services, the customers want to receive benefits which arise not only from using the services. This value dimension becomes important in a situation when it is difficult to evaluate a product or service, even after their consumption (Zeithaml et al., 2009), as it is the case with tourism services. The ability of staff to establish a relationship with a client depends primarily on their communication skills. Dimensions such as acquired competencies, understanding, commitment and efficiency contribute to improving the quality of interaction as a key element of customer perceived value (Chandon et al., 
1997). Customers of tourism services expect the staff in travel agencies to possess the knowledge and skills necessary for providing various information related to travels, as well as providing other services they need. Customers evaluate respect, understanding, paying attention to each customer, as well as the speed in providing services. If staff in a travel agency shows interest for their customers, meet their needs at any moment etc., customers will build confidence and feel satisfied, which leads to establishing long-term relationships and creating loyal customers. In this way a confidence in relationship quality is built, which encourages the use of services in the future as well, or more precisely, the customers become more satisfied and eventually committed to the given services.

\subsection{The Impact of Perceived Value on Customer Loyalty}

Loyalty can be defined as a customer's commitment to one company over a longer period, at the same time supported by his/her readiness to recommend the company and its products and/or services to other people. The loyalty concept consists of behavioural and attitudinal components. Loyalty based on behaviour represents an intention to use a product or service again and thereby it includes also amount and frequency (Lewis and Soureli, 2006).

On the other hand, the attitudinal component refers to preferences, customer's confidence toward the product or service, as well as toward a word of mouth (Zeithaml et al., 1996). In general, customer loyalty is manifested in the form of two types of behaviour (Zeithaml et al., 1996):

- repurchase intention,

- willingness to recommend.

Repurchase intention, as one of the dimensions of loyalty, aims to show whether the customer will maintain a relationship with the company in the future. On the other hand, word of mouth shows to what extent the customer will inform his/her colleagues, friends, relatives and acquaintances about own previous experience. Those customers who are willing to show positive impressions of service companies will probably continue themselves to use the services of that company in the next period (Eisingerich and Bell, 2007). Thus, the customer will be loyal to a specific company if he has a habit of repeating purchase of its products and/or services, but also of spreading positive word of mouth and attracting new customers to the company. Bearing in mind the above mentioned, measuring the customer loyalty involves testing the level of future purchase intention, as well as the level of customer's willingness to recommend the company to his/her friends and acquaintances.

Marketing literature has confirmed that customer perceived value has a direct impact on purchase intention (Zeithaml, 1988). Since it is a prepurchase 
phase, the impact of value on the satisfaction is ignored. Numerous studies have a different view of the relationship between perceived value, satisfaction and loyalty. Based on the existing studies, some authors such as Liljander and Strandvik (1992); Spreng and Patterson (1997); Ravald and Gronroos (1996) support the view of a direct impact of perceived value on customer satisfaction. Results of the research conducted by McDougall and Levesque (2000); Hu et al. (2009) confirm that value has an indirect impact on repurchase intention, as one of the components of loyalty achieved through customer satisfaction. Namely, the value of product/service is seen as a precondition to achieve customer satisfaction and intention of customers to consume the same product/service in the future. Those customers who received superior value from a product/service often prefer a given company and recommend it to others (Hu et al., 2009). Whether customers will repeat purchase from the same company in the coming period and be willing to share positive impressions with others, depends on the perceived value they received from previous experiences (Bolton et al., 2000), but also on expected future relationships where the quality of interaction is seen as a substitution for expected benefits in the future (Olaru et al., 2008). Involving the value in models for measuring customer satisfaction and loyalty enables a more detailed view of customer assessment of satisfaction and commitment to the specific company and its products and/or services.

\section{Research Methodology}

In order to examine the level of customer loyalty to various value dimensions of travel agencies' offerings, empirical research was conducted using the questionnaire method. The questionnaire method is the most commonly used method when it comes to field research. The research included 157 respondents who live in the Raska District. Collecting the primary data based on the questionnaire was carried out in the period 28.05-15.07.2014. The questionnaires were forwarded to customers of 14 travel agencies, whose staff supported distribution and collection of questionnaires.

Before distribution, the questionnaire was tested on a small sample of 20 respondents. In order to remove the ambiguities from the questionnaire, a preliminary testing was conducted. Also, in order to make the questionnaire clear and concise, the researcher organized a group discussion with travel agency staff. After preliminary testing and discussion, the field research was conducted.

The questionnaire contained three parts. The first part included 9 statements which represent three value dimensions of the travel agency's service offers: prestige, value for money and interaction quality. The statements were selected and adapted on the basis of relevant marketing literature (Olaru et al., 2008; Nasution and Mavondo, 2008). The second part included 5 statements which were related to the loyalty components. In other words, loyalty was measured 
on the basis of 5 statements, 3 of which referred to the willingness of the customers to recommend the travel agency to their friends and relatives, and 2 statements were focused on customer's intention to use the services of the given agency in the future as well. It has already been stated that repurchase intention and positive word of mouth represent two key dimensions of loyalty. The statements which refer to loyalty are taken from the study of Gaur and his associates (Gaur et al., 2011). In addition to the above mentioned statements, the questionnaire also included questions referring to the information about respondents (gender, age and education). Respondents expressed the level of agreement with the statements on the seven-grade Likert scale, where 1 means that the respondent absolutely disagrees with the statement, and 7 means absolute agreement with the statement. This formed the basis for the analysis of the impact of key value dimensions on loyalty. Table 1 shows the dimensions of value and loyalty, including a total of 14 statements.

Table 1 Value Dimensions of Travel Agencies' Services and Customer Loyalty

\begin{tabular}{|c|c|}
\hline Value dimensions & Statements \\
\hline Prestige & $\begin{array}{l}\text { Using the services of the given agency is considered prestigious. } \\
\text { Using the services of the agency represents a status symbol. } \\
\text { Using the services of the agency is in accordance with your } \\
\text { social status. }\end{array}$ \\
\hline Value for money & $\begin{array}{l}\text { Prices of arrangements in the agency are very convenient. } \\
\text { The ratio of arrangement price and service quality is very } \\
\text { convenient. } \\
\text { Booking system of the travel agency is suitable for you. }\end{array}$ \\
\hline $\begin{array}{l}\text { Interaction } \\
\text { quality }\end{array}$ & $\begin{array}{l}\text { The staff recognizes and understands the needs of their } \\
\text { customers. } \\
\text { Every promise given to customers is verified in a stated period. } \\
\text { The staff is willing to help their customers in every moment. }\end{array}$ \\
\hline $\begin{array}{l}\text { Loyalty } \\
\text { dimenstions }\end{array}$ & Statements \\
\hline Word of mouth & $\begin{array}{l}\text { You are willing to share good impressions about the travel } \\
\text { agency to your friends and acquaintances. } \\
\text { You are willing to recommend the travel agency to your friends } \\
\text { and acquaintances. } \\
\text { You are willing to encourage your friends to visit the travel } \\
\text { agency if they would like to travel. }\end{array}$ \\
\hline $\begin{array}{l}\text { Repurchase } \\
\text { intention }\end{array}$ & $\begin{array}{l}\text { You think that your friends would also choose this agency of } \\
\text { they would undertake a travel. } \\
\text { You will continue using the services of the given agency also in } \\
\text { the future. }\end{array}$ \\
\hline
\end{tabular}


In an analysis of collected data following methods were used: descriptive analysis, correlation and multi-point regression. First, descriptive statistical analysis was conducted on the entire sample. Out of the measures of descriptive statistics for each statement the arithmetic mean and standard deviation were calculated. Therewith the level of satisfaction with different elements of the value of travel agencies' services was measured and the level of homogeneity among customers' attitudes was determined. In the next step a correlation analysis was implemented in order to identify the level of interdependence of all variables. Finally, for the purpose of identifying the statistically significant impacts of the determined values on two parameters of loyalty of the travel agencies' customers a multi-point regression was applied for both parameters. The problem of multicollinearity was tested through the value of VIF (Variance Inflation Factor). Data analysis was implemented using the SPSS 12 (the Statistical Package for the Social Sciences).

Table 2 Demographic Characteristics of Survey Participants (n=157)

\begin{tabular}{|c|c|c|}
\hline Demographic profile & Number of participants (n) & Percentage (\%) \\
\hline Gender & & \\
\hline female & 97 & $62 \%$ \\
\hline male & 60 & $38 \%$ \\
\hline Age & & \\
\hline $18-24$ & 24 & $15 \%$ \\
\hline $25-31$ & 38 & $24 \%$ \\
\hline $32-38$ & 36 & $23 \%$ \\
\hline $39-45$ & 25 & $16 \%$ \\
\hline $46-52$ & 16 & $7 \%$ \\
\hline $53-59$ & 11 & $5 \%$ \\
\hline 60 and more & 7 & $38 \%$ \\
\hline Education & & $27 \%$ \\
\hline Elementary school & $/$ & 10 \\
\hline High school & 55 & \\
\hline Associate degree & 43 & \\
\hline University & 59 & \\
\hline
\end{tabular}

When observing the structure of the sample given in Table 2, it can be concluded that the sample included more female respondents (97) than male (60). 
When it comes to age, $15 \%$ of the respondents are aged between 18 and 24, 24\% of the respondents are between 25 and 31 years old, $23 \%$ are in the age group between 32 and $38,16 \%$ are those respondents aged between 39 and $45,10 \%$ between 46 and 52 years old, $7 \%$ of the respondents are between 53 and 59 years old and 5\% are those older than 60 years. This is to conclude that all age groups were present. The sample consists mainly of respondents of two age groups: between 25 and 31 and between 32 and 38, in almost equal number, while respondents over 60 years old were at least present. Considering the education level of the respondents, the majority of respondents have completed university (38\%) and high school (35\%) while $27 \%$ of the respondents have an associate degree. In the sample there were no respondents who completed elementary school only, which speaks to the fact that those are people who have not developed a culture of travelling.

\section{Discussion of the Results Obtained}

Table 3 shows the results of descriptive statistics. Implementation of descriptive statistical analysis resulted in calculation of the arithmetic mean and standard deviation for each statement. The results of the analysis based on the entire sample indicate that the assessments of the respondents range in the interval 5,06-5,83.

Table 3 Results of the Descriptive Analysis

\begin{tabular}{|l|l|c||}
\hline Statements & M & SD \\
\hline Using the services of the given agency is considered prestigious. & 5,10 & 1,262 \\
\hline Using the services of the agency represents a status symbol. & 5,17 & 1,178 \\
\hline Using the services of the agency is in accordance with your social status. & 5,30 & 1,179 \\
\hline $\begin{array}{l}\text { Prices of arrangements in the agency are very convenient. } \\
\text { Booking system of the travel agency is suitable for you. }\end{array}$ & 5,06 & 1,218 \\
\hline The ratio of arrangement price and service quality is very convenient. & 5,24 & 1,215 \\
\hline Booking system of the travel agency is suitable for you. & 5,46 & 1,269 \\
\hline The staff recognizes and understands the needs of their customers. & 5,66 & 1,159 \\
\hline Every promise given to customers is verified in a stated period. & 5,71 & 1,215 \\
\hline \begin{tabular}{l} 
The saff is willing to help their customers in every moment. \\
\hline $\begin{array}{l}\text { You are willing to share good impressions about the travel agency to } \\
\text { your friends and acquaintances. }\end{array}$
\end{tabular} & 5,61 & 1,338 \\
\hline $\begin{array}{l}\text { You are willing to recommend the travel agency to your friends and } \\
\text { acquaintances. }\end{array}$ & 5,79 & 1,176 \\
\hline $\begin{array}{l}\text { You are willing to encourage your friends to visit the travel agency if } \\
\text { they would like to travel. }\end{array}$ & 5,62 & 1,421 \\
\hline $\begin{array}{l}\text { You think that your friends would also choose this agency of they would } \\
\text { undertake a travel. }\end{array}$ & 5,09 & 1,346 \\
\hline You will continue using the services of the given agency also in the future. & 5,49 & 1,470 \\
\hline
\end{tabular}

$$
M \text { - arithmetic mean; } S D \text { - standard deviation }
$$


The respondents are moderately satisfied with the value of services provided by travel agencies. The lowest grades belong to the statement that the prices of arrangements in travel agencies are very convenient, where the arithmetic mean is 5,06. The highest grade is to note for the statement which expresses the willingness of the customers to recommend the given travel agency (the arithmetic mean 5,83). The results point out that the customers are more willing to recommend than to continue themselves the cooperation with the travel agency in the future. Generally, the total sample demonstrates a moderate level of loyalty. Beside the arithmetic mean, the values of standard deviation were also calculated which show the level of agreement or disagreement of the respondents with the given statements. For all statements, the values of standard deviation range between $1,159-1,470$. It can be concluded that there is a similar level of heterogeneity, respectively of disagreement of the respondents concerning the assessment of all 14 statements.

Table 4 Reliability of Dimensions - Values Cronbach's Alpha

\begin{tabular}{|c|c|}
\hline Dimensions & Cronbach's alpha \\
\hline Prestige & 0,779 \\
\hline Value for money & 0,853 \\
\hline Interaction quality & 0,796 \\
\hline Word of mouth & 0,945 \\
\hline Repurchase intention & 0,869 \\
\hline
\end{tabular}

In order to determine internal consistency of every statement grouped in five dimensions, the Cronbach's alpha coefficients were calculated. Based on the values of this coefficient, the reliability of the variables was determined, given that they were measured through a large number of statements. The Cronbach's alpha values range in the interval from 0 to 1 . Nunnally (1078) suggests that the reliability threshold should not be lower than 0,7 . The Table 4 shows the values of alpha coefficient. In this study, all dimensions demonstrate high values of alpha coefficient, indicating that all five dimensions have a high level of reliability and all statements grouped around them are internally consistent.

Subsequently the correlation was applied in order to identify the level of interdependency among the variables. The level of interdependency of the variables was measured through Pearson's linear correlation coefficient. The results of the correlation matrix, given in Table 5, show that all correlations are statistically significant. The highest level of dependence is achieved between the Word of mouth and the Repurchase intention $(0,837)$ while the weakest correlation is the one between the Prestige and the Word of mouth $(0,404)$. 
Tabela 5. Korelaciona matrica

\begin{tabular}{|c|c|c|c|c|c||}
\hline & Prestige & $\begin{array}{c}\text { Value for } \\
\text { money }\end{array}$ & $\begin{array}{c}\text { Interaction } \\
\text { quality }\end{array}$ & $\begin{array}{c}\text { Word of } \\
\text { mouth }\end{array}$ & $\begin{array}{c}\text { Repurchase } \\
\text { intention }\end{array}$ \\
\hline Prestige & 1 & & & & \\
\hline $\begin{array}{c}\text { Value for } \\
\text { money }\end{array}$ & $0,514^{* *}$ & 1 & & & \\
\hline $\begin{array}{c}\text { Interaction } \\
\text { quality }\end{array}$ & $0,576^{* *}$ & $0,752^{* *}$ & 1 & 1 & \\
\hline $\begin{array}{c}\text { Word of } \\
\text { mouth }\end{array}$ & $0,404^{* *}$ & $0,723^{* *}$ & $0,762^{* *}$ & $0,837^{* *}$ & 1 \\
\hline $\begin{array}{c}\text { Repurchas } \\
\text { e intention }\end{array}$ & $0,473^{* *}$ & $0,692^{* *}$ & $0,716^{* *}$ & 0 \\
\hline
\end{tabular}

Table 6 Results of Multi-Point Regression (Dependent Variable: Word of Mouth)

\begin{tabular}{|c|c|c|c|}
\hline Variables & B & $\mathbf{t}$ & VIF \\
\hline Prestige & $-0,097$ & $-1,618^{\mathrm{ns}}$ & 1,531 \\
\hline Value for money & 0,364 & $4,885^{* *}$ & 2,351 \\
\hline Interaction quality & 0,545 & $6,977^{* *}$ & 2,588 \\
\hline
\end{tabular}

The results are significant at the level of: $\mathrm{p}<0,01(* *)$; Results are not significant: $\mathrm{p}>$ $0,05(\mathrm{~ns}) ; \mathrm{R} 2=0,639$

Table 7 Results of Multi-Point Regression (Dependent Variable: Repurchase Intention)

\begin{tabular}{|c|c|c|c|}
\hline Variables & B & t & VIF \\
\hline Prestige & 0,049 & $0,741^{\mathrm{ns}}$ & 1,531 \\
\hline Value for money & 0,345 & $4,232^{* *}$ & 2,351 \\
\hline Interaction quality & 0,429 & $5,025^{* *}$ & 2,588 \\
\hline
\end{tabular}

Results are significant at the level of: $\mathrm{p}<0,01(* *)$; Results are not significant: $\mathrm{p}>0,05$ $(\mathrm{ns}) ; \mathrm{R} 2=0,569$

After descriptive statistics, determining the reliability of value dimensions and loyalty and applied correlation, the multi-point regression analyses were conducted. The first regression analysis was implemented with the objective of determining the impact of prestige, value for money and interaction quality on word of mouth as the dependent variable. The analysis results, listed in Table 6, confirm the statistically significant impact of two independent variables (value for money: $\beta=0,364, t=4,885$; interaction quality: $\beta=0,545, t=6,977$ ), while prestige proved to be statistically insignificant driver of word of mouth ( $\beta=$ $0,097, \mathrm{t}=-1,618, \mathrm{p}>0,05)$. Independent variables explain about $64 \%$ of variabilities of word of mouth. 
In the second step, by using multi-point regression, we determined the impact of three independent variables (prestige, value for money, interaction quality) on repurchase intention (dependent variable). The results of the implemented regression (Table 7) show that two variables: value for money $(B=$ $0,345, \mathrm{t}=4,232)$ and interaction quality $(\beta=0,429, \mathrm{t}=5,025)$ represent significant antecedents of repurchase intention. Statistically significant impact was not proven in the case of prestige $(\beta=0,049, \mathrm{t}=0,741, \mathrm{p}>0,05)$. Nevertheless, these three independent variables explain about $57 \%$ of variabilities of the dependent variable.

The study examined the existence of the problem of multicollinearity. This problem was tested using the values of VIF coefficient. If the value of the given coefficient is higher than 5 , the multicollinearity represents a serious problem in the implemented study (Field, 2000). In this research, implementing two multipoint regressions, appropriate values of VIF coefficient were obtained, in the range 1,531-2,588.

\section{Conclusion}

Delivering superior value to the customers represents one of the most important conditions for achieving and maintaining competitive advantage of service-oriented companies. In a market where there is strong competition, there is also a struggle to win every single customer. Modern service-oriented companies must focus their marketing activities towards creating and maintaining long-term relationships with their customers. Loyal customers are the key for achieving profitability in the long term. Thus, it is necessary for every service-oriented company to identify the key loyalty drivers of their customers, in order to continue and improve the relationships with them.

For the purpose of this paper the research was conducted, in order to determine the key value dimensions of the travel agencies' services which have the greatest influence on customer loyalty, through its two dimensions: word of mouth and willingness to use the services again in the future. The participants of the survey generally graded up the statements contained in the questionnaire. The assessments of 157 respondents testify to the existence of their moderate satisfaction with the travel agencies' services. Therefore, it can be concluded that the travel agencies operate well in the Raska District.

The findings of two conducted regression analyses point out that value for money and interaction quality achieve a statistically significant influence on word of mouth and repurchase intention, as key dimensions of customer loyalty. At that point, interaction quality is the most significant antecedent of customer loyalty, and after that value for money. Based on the results, it can be concluded that courtesy, kindness and cooperativeness of the employees towards the 
customers, as elements of interaction quality, influence the customer loyalty in a higher degree than the value they receive for the invested money. On the other hand, prestige proved to be a non-significant driver of customer loyalty. The results obtained indicate that the respondents, because of their social status and purchasing power, tend to purchase travel via local travel agencies which do not have built a status symbol in the community. Namely, the respondents do not intend to purchase services, nor demonstrate the willingness to recommend the renowned and prestigious agencies which offer more expensive arrangements, bearing in mind that their discretionary income is at the lower level.

In further research, it is desirable to include also other value dimensions in the questionnaire, with an aim of obtaining a more detailed review of the impact on customer loyalty. Furthermore, this study was restricted to examining dimensions of loyalty of the travel agencies' customers. Considering the great diversity of companies in the service sector, future researchers could examine the impact of value dimensions of customers toward other service companies.

\section{References}

Bergami, M. and R. P. Bagozzi (2000) "Self-categorization, affective commitment and group self-esteem as distinct of social identity in the organization", British Journal of Social Psychology, 39 (4): 555-577.

Bolton, R., P. Kannan, and M. Bramlett (2000) "Implications of loyalty program membership and service experiences for customer retention and value", Journal of the Academy of Marketing Science, 28 (1): 95-108.

Chandon, J. L., P. Y. Leo, and J. Philippe (1997) "Service encounter dimensions - a dyadic perspective: measuring the dimensions of service encounters as perceived by customers and personnel", International Journal of Service Industry Management, 8 (1): 65-86.

Eisingerich, A. B. and S. F. Bell (2007) "Maintaining customer relationships in high credence services", Journal of Services Marketing, 21 (4): 253-62.

Field, A. (2000) Discovering statistics using SPSS for Windows, Thousand Oaks, USA: Sage Publication.

Gallarza, M. G. and I.G. Saura (2006) „Value dimensions, perceived value, satisfaction and loyality: an investigation of university students' travel behavior", Tourism Management, 27 (3): 437-452.

Gaur, S. S., Y. Xu, A. Quazi, and S. Nandi (2011), Relational impact of service providers' interaction behavior in healthcare", Managing Service Quality, 21 (1): 67-87.

Holbrook, M. (2007) Consumer Value: A Framework for Analysis and Research, New York: Taylor \& Francis.

Hu, H., J. Kandampully, and D.T. Juwaheer (2009) „Relationships and impacts of service quality, perceived value, customer satisfaction, and image: an empirical study“, The Service Industries Journal, 29 (2): 111-12. 
Johnson, W. and A. Weinstein (2004) Superior customer value in the new economy: concepts and cases, Boca Raton: CRC Press.

Lapierre, J. (2000) "Customer-perceived value in industrial contexts", Journal of Business \& Industrial Marketing, 15 (2/3): 122-40.

Lewis, B. R. and M. Soureli (2006) "The antecedents of consumer loyalty in retail banking", Journal of Consumer Behaviour, 5 (1): 15-31.

Liljander, V. and T. Strandvik (1992), "The relationship between service quality, satisfaction and intentions", No. 273, The Swedish School of Economics and Business Administration, Helsinki.

Maričić B., i A. Đorđević (2012) Kreiranje i isporučivanje vrednosti potrošačima, Beograd: Centar za izdavačku delatnost Ekonomskog fakulteta u Beogradu.

McDougall, G. and T. Levesque (2000) „Customer satisfaction with services: Putting perceived value into the equation“", Journal of Services Marketing, 14 (5): 392-410.

Milisavljević, M., B. Maričić, i M. Gligorijević (2007) Osnovi marketinga, Beograd: Centar za izdavačku delatnost Ekonomskog fakulteta u Beogradu.

Murphy, R. (2002) "The correlative relationship between value, price and cost", Journal of American Academy of Business, 2 (1): 204-10.

Nasution, H. N. and F. T. Mavondo (2008) "Customer value in the hotel industry: What managers believe they deliver and what customer experience", International Journal of Hospitality Management, 27 (204-213).

Nunnally, J. C. (1978) Introduction to psychological measurement, New York: McGraw-Hill.

Olaru, D., S. Purchase, and N. Peterson (2008) „From customer value to repurchase intentions and recommendations“, Journal of Business \& Industrial Marketing, 23 (8), doi 10.1108/08858620810913362

$\mathrm{Ou}$, W. M. and R. Abratt (2006) „Diagnosing the relationship between corporate reputation an retail patronage“, Corporate Reputation Review, 9 (4): 243-257.

Petrick, J. F. (2002) "Development of a multi-dimensional scale for measuring the perceived value a service", Journal of Leisure Research, 34 (2): 119-134.

Ravald, A. and C. Gronroos (1996) "The value concept and relationship marketing", European Journal of Marketing, 30 (2): 19-30.

Spreng, R. A. and P. G. Patterson (1997) „Modelling the relationship between perceived value, satisfaction and repurchase intentions in a business-to-business, services context: an empirical examination", International Journal of Service Industry Management, 8 (5): 414-434.

Stanković, Lj. i S. Đukić (2009) „Marketing strategija orijentisana na vrednost“, Markeitng, 40 (2): 73-79.

Sweeney, J. C. and G. N. Soutar (2001) "Consumer perceived value: the development of a multiple item scale", Journal of Retailing, 77 (2): 203-220.

Sweeney, J. and D. Webb (2007) "How functional, psychological, and social relationship benefits influence individual and firm commitment to the relationship", Journal of Business \& Industrial Marketing, 22 (7): 474-488.

Teas, R. and S. Agarwal (2000) "The effects of extrinsic product cues on consumers' perceptions of quality, sacrifice, and value", Journal of the Academy of Marketing Science, 28 (2): 278-290. 
Woodruff, R. B. (1997) "Customer value: The next source of competitive advantage", Journal of the Academy of Marketing Science, 25 (2): 139-153.

Zeithaml, V. A. (1988) "Consumer perceptions of price, quality, and value: A means-end model and synthesis of evidence", Journal of Marketing, 52 (3): 2-22.

Zeithaml, V. A., L. L. Berry, and A. Parasuraman, (1996) "The behavioral consequences of service quality", Journal of Marketing, 60 (2): 31-46.

Zeithaml, V., M. Bitner, and D. Gremler (2009) Services Marketing: Integrating Customer Focus across the Firm, $6^{\text {th }}$ ed., Boston: McGraw-Hill, MA.

\section{UTICAJ DIMENZIJA PERCIPIRANE VREDNOSTI NA LOJALNOST KLIJENATA}

Apstrakt: U uslovima intenzivne konkurencije, nije dovoljno postići samo zadovoljstvo klijenata. Marketinški orijentisana preduzeća moraju biti fokusirana na izgradnju dugoročne lojalnosti klijenata. Kreiranje i isporuka superiorne vrednosti predstavljaju jedne od ključnih aktivnosti ostvarenja i održavanja konkurentske prednosti. Ova studija nastoji da ispita kako različite dimenzije vrednosti usluga turističkih agencija utiču na dve važne dimenzije lojalnosti: nameru za ponovnim korišćenjem usluga i preporuku istih drugima. Primarni podaci prikupljeni su anketnom metodom. U studiji su za analizu podataka korišćene deskriptivna statistika, korelacija i višestuka regresija. Rezultati istraživanja ističu dve ključne dimenzije percipirane vrednosti koje ostvaruju statistički značajan uticaj na lojalnost: kvalitet interakcije i vrednost za novac. Identifikacija ključnih dimenzija percipirane vrednosti kao pokretača lojalnosti je od suštinskog značaja za uslužno orijentisana preduzeća, jer na ovaj način ona stiču mogućnosti za unapređenje budućih poslovnih odnosa sa klijentima.

Ključne reči: percipirana vrednost, dimenzije vrednosti, usmena propaganda, namera ponovne kupovine, uslužna preduzeća 